Please do not remove this page

RMIT

UNIVERSITY

\title{
Entrepreneurial configurations of small firms
}

de Villiers Scheepers, M.; Verreynne, Martie-Louise; Meyer, Denny

https://researchrepository.rmit.edu.au/esploro/outputs/9921858949201341/filesAndLinks?institution=61RMIT_INST\&index=null

De Villiers Scheepers, M., Verreynne, M.-L., \& Meyer, D. (2014). Entrepreneurial configurations of small firms. International Journal of Entrepreneurial Behaviour and Research, 20(6), 562-583.

https://doi.org/10.1108/IJEBR-09-2013-0135

Document Version: Accepted Manuscript

Published Version: https://doi.org/10.1108/IJEBR-09-2013-0135

Repository homepage: https://researchrepository.rmit.edu.au

(C) 2014 Emerald Group Publishing Limited

Downloaded On 2023/04/26 15:26:00 +1000 


\title{
Entrepreneurial Configurations of Small Firms
}

\begin{abstract}
Purpose - This article develops contemporary entrepreneurial configurations of small firms and relates them to performance. Adding a process dimension, we extend the more commonly used resource and growth taxonomies in this field of research.

Design/methodology/approach - A review of current literature on small firm configurations is followed by a discussion of its dimensions, namely, context (external and internal environment), content (entrepreneurial orientation), and process (strategy-making). These are related to perceived performance, using cluster analysis and ANOVA for a sample of 320 small New Zealand firms.
\end{abstract}

Findings - The results isolate young corporates, young simple, and mature consolidator clusters. Young corporates outperform their counterparts in dynamic environments in how they use formal structures, and their high entrepreneurial orientation and generative strategy-making.

Research limitations/implications - This study uses self-reporting measures and a cross-sectional design.

Practical implications - Our findings show how young, small firms can enhance their performance practically by aligning the key dimensions of an entrepreneurial configuration. These firms could benefit from early formalization of systems and structures, a high EO, and by using a generative strategy-making approach.

Originality/value - Our contribution is threefold. First, we empirically verify the existence of three clusters of small firms and then link these to perceived performance. Second, by basing our small-firm configurations on a CCP framework, we highlight the importance of aligning these dimensions to performance. Third, we find evidence of the role of early formalization to accompany generative strategymaking and EO if small firms want to improve performance outcomes.

Keywords: Entrepreneurial configuration, entrepreneurial orientation, generative strategy-making, perceived performance

Paper Type: Research Paper 


\section{Introduction}

Numerous contingency studies show the importance of an entrepreneurial orientation (EO) for small-firm performance (see Covin \& Slevin, 1989; Lumpkin \& Dess, 1996; Wiklund, 1999; Rauch et al., 2009). While some small-firm configuration studies examine inter-related organizational dimensions and link these to performance (Andersén, 2012; Ketchen and Shook, 1996), few studies acknowledge the role that process plays in these EO configurations and their relationship with performance. As a result, a number of authors have called for studies using a configuration or 'gestalt' approach (Payne et al., 2009; Short et al., 2008; Steffens et al., 2009; Wiklund and Shepherd, 2005).

Configuration research concentrates on firms that share sets of characteristics, such as strategy, structure, and goals (Andersén, 2012), which are meaningful collectively rather than individually (Dess et al., 1997). Within this broader research stream, Hakala and Kohtamäki (2011), Payne et al. (2009) and Snow et al. (2005) identify that configuration research often neglects EO and organizational processes, which are important to enhance our understanding of the multi-dimensionality of small-firm entrepreneurship. We address this gap by examining the complex interrelationships of EO with the strategy-making process in a small-firm context (organizational structure and external environmental) to reveal three small-firm configurations that can explain differences in small-firm performance (Andersén, 2012; Doty et al., 1993; Miller 1988).

While most researchers develop and test explanatory models to determine strategic posture, and resource and growth taxonomies (Andersén, 2012; Bantel, 1998; Borsch et al., 1999; Delmar et al., 2003; McMahon, 2001), we attempt rather to understand small-firm clusters by emphasizing differences in context (external and 
internal structure), content (entrepreneurial orientation), and process (strategy making) between clusters and then relate these to performance. We use Pettigrew's (1985) seminal content, context, process (CCP) approach and apply this framework to structure our small-firm configurations. The selection of the CCP approach has three advantages. First, there is widespread acceptance of the CCP framework among the broader small-business and strategy fields (Dess et al., 2003; Ng and Keasey, 2010; Regner, 2003). Second, the concepts are broad enough to accommodate our configuration dimensions and thus provide a parsimonious framework. Third, the CCP approach is holistic, with interdependencies acknowledged and distinctions between performance levels of different configurations highlighted. To support this approach, we use cluster analysis. It is a useful multivariate statistical approach for our purposes because it works with natural groupings in data so that firms can be classified into clusters based on shared or common characteristics (Hair et al., 2010). Once the clusters are defined, the configuration analysis can then use standard statistical methods to understand how other important variables such as industry and performance relate to these clusters.

Configuration research is useful in explaining small-firm performance (Doty et al., 1993; Ketchen et al. 1993), as evidenced in the popularity of typologies in entrepreneurship and small-business journals (e.g., Bantel, 1998; Hanks et al., 1993; Wiklund and Shepherd, 2005; Green et al., 2008; Steffens et al., 2009; Andersén, 2012). This research allows us to achieve the three main goals of entrepreneurship research, namely, description, explanation and prediction (Short et al., 2008). Description of similar groups on important dimensions provides rich images and captures the complexities within small firms, as opposed to oversimplification that often occurs in contingent studies. Explanation of entrepreneurial phenomena leads to 
better understanding by "identifying distinct, internally consistent sets of firms rather than seeking to uncover relationships that holds across all organizations" (Ketchen et al., 1993, p. 1278) and linking these to performance outcomes. Prediction underlies the logic of configuration theory in that it argues that sets of firms able to align key attributes will outperform other firms in the same industry under a particular set of circumstances (Andersén, 2012; Delmar et al., 2003). In addition, configuration research provides practical value for small-firm owner/managers by showing how the alignment of dimensions of the CCP framework can relate to improved performance.

This article therefore aims to describe, explain and predict the role of entrepreneurship in small-firm configurations with different performance levels. We contribute to the entrepreneurship literature in three ways. First, we identify and empirically verify the existence of three clusters of small firms, namely, young corporates, young simple, and mature consolidator firms and then link these to perceived performance. Second, following the suggestion of Hakala and Kohtamäki (2011), Payne et al. (2009) and Snow et al. (2005), we add generative strategymaking and EO to our small-firm configurations for two reasons. First, this approach covers all aspects of the context-content-process (CCP) framework; and second, it enhances our understanding of the multi-dimensionality of how small firms align these dimensions. Third, the use of cluster analysis shows that young corporates with high levels of EO, generative strategy-making, and formalization, display higher levels of performance. These structures enable young firms to formalize their managerial capabilities and reap performance benefits.

Our article is organized as follows. We proceed by outlining configuration typologies and their dimensions based on research mainly conducted in large firms. We then describe our review of the literature on small-firm configurations and relate 
it to our study. We then use cluster analysis in a sample of 320 small New Zealand firms, defined as those firms with fewer than 100 full-time equivalent employees. Lastly, we discuss the findings, implications and limitations of the study.

\section{Organizational configurations}

A number of authors have investigated the nature and outcomes of configurations in the broader fields of strategy and entrepreneurship (e.g., Dess et al., 1997; Miller and Friesen, 1978; Murimbika and Urban, 2013). For example, Miles and Snow's (1978) typology of prospectors, defenders, analyzers and reactors has been used widely to classify firms (Hambrick, 2003) and has been successfully applied to small firms (see Borsch et al., 1999; McCann et al., 2001; Aragon-Sanchez and Sanchez-Marin, 2005). Similarly, Porter's (1980) generic competitive strategy types of cost leadership, differentiation, or a focus strategy have been widely studied. Small business researchers have tested the efficacy of these competitive strategy types (e.g., Leitner and Guldenberg, 2009; Lee, et al., 1999; Verreynne and Meyer, 2011) to find clusters of low-cost and differentiation strategies, but also of small firms that use a combination of these strategies simultaneously, or no strategy at all. However, generic strategy types often oversimplify firm behavior by only relating firm demographic factors and competitive strategy to performance, and thus fail to take into account multi-dimensional factors (such as external and internal context) inherent in configurations.

Environmental uncertainty as a contextual variable in configurations also provides insight into firm behavior. The literature finds that both hostile and dynamic environments are likely to stimulate firm entrepreneurial behavior, while stable or 
impoverished environments favor conservative behavior and mature firms (Miller, 1983; Zahra, 1993; Zahra and Bogner, 1999; Antoncic and Hisrich, 2001).

Configuration studies often use variables such as strategy, structure and environment to form "gestalts" (Miller, 1987). In essence, these dimensions map well to the CCP framework (Pettigrew, 1985). Context includes the internal and external conditions in which content and process are embedded, such as environmental dynamism and internal organizational structure. Content represents the effect of the strategy process: referring to a firm's approach to markets, responsiveness and synergies. As Wiklund and Shepherd (2005, p. 74) explain, EO "reflects how a firm operates rather than what it does". In other words, EO can be seen as reflective of a managerial orientation (philosophy). Process refers to the way strategies and actions come about, that is, the strategy-making approach of a firm (Hart, 1992). Our article uses this same approach in identifying the dimensions of the configurations, and thus aiming to portray the complexity of small-firm realities (Andersén, 2012; Dess et al., 1997), while incorporating EO and strategy-making as content and process dimensions (called for by Snow et al., 2005).

\section{Small firm configurations}

Configurations developed for categorizing larger firms do not accurately depict small-firm 'gestalts', given that the challenges, limited resource base, and stage of development of small firms differ dramatically from larger firms (Andersén, 2012; Wagner and Hansen, 2005; Zahra and George, 1999). To find small-firm configurations pertaining to our CCP framework, we reviewed articles from influential entrepreneurship and small business journals. We manually searched these journals identified by the Thompson Reuter's ISI Web of 
Science Social Citation Index, using keywords such as entrepreneurial configurations, typologies, taxonomies and small-firm performance. These journals were Entrepreneurship Theory and Practice, Journal of Business Venturing, Small Business Economics, Journal of Small Business Management, International Small Business Journal and also the International Journal of Entrepreneurial Behavior and Research.

This search strategy yielded a total of 72 studies. To be included in our smallfirm configuration typology review, the studies had to meet three criteria. First, we only considered studies examining configurations and performance on the firm-level. Therefore, studies at the individual or industry-level of analysis were excluded. Second, studies had to examine small firms. To ensure that we covered the broadest range of literature; we included all research that focused on small and medium enterprises. This meant that our papers focused on anything up to 500 employees (Rosenbusch et al., 2011), seeing that the definition of what are small or medium enterprises differs between countries. Third, studies needed to include at least one of the configuration dimensions of interest (context-content-process variables such as external environmental factors, internal factors [age, size, organizational structure], entrepreneurial orientation or strategy-making) in addition to firm performance (perceived financial or growth measures). Applying these three criteria to the 72 articles led to ten articles summarized in Table I. Small-firm configurations depicting firms' generic strategies, growth paths, strategic groups, innovation configurations, internationalization, and information technology configurations were excluded as they fell outside the scope of our study. 
Table 1 summarizes the ten articles relevant to our three criteria for small-firm configuration studies incorporating measures of entrepreneurial behavior. Our intention was not to exhaustively review all small-firm configurations, but merely to identify, by using a systematic and transparent methodology, the main research thrusts of prior empirical research related to small-firm configurations.

A number of important themes emerge from this analysis. First, the small-firm configuration studies in Table 1 show a number of authors focusing on strategic posture (e.g., Borsch et al., 1999), who identify four clusters, namely managerial, technological, traditional and impoverished firms. Both Wiklund and Shepherd (2005) and Hakala and Kohtamäki (2011) include EO configurations and relate these to performance. Wiklund and Shepherd (2005) show that a higher EO is often associated with dynamic environments and improved performance. As well, Hakala and Kohtamäki, in their sample of 164 Finnish software firms, indicate how strategic orientations (including EO) and organizational learning impact upon perceived financial performance. These studies highlight the value of the configuration approach to provide a more holistic picture of small-firm performance.

Second, the firm stage of development (size and age) is relevant to the smallfirm configuration adopted. Hanks et al.'s (1993) seminal article examines small-firm venture life-cycle typologies and demonstrates how firm size, age, growth rate, structural form, and performance change over time. These authors classify firms in six clusters, where the first four: start-ups, expansion, later expansion/early maturity and maturity/diversification follow the venture life-cycle model (Greiner, 1972), while the latter two clusters, older and small firms, do not. Hanks et al. (1993) emphasize the importance of taking firm size, age and structural form into account 
when studying small-firm configurations. Other studies (e.g., Anderson and Eshima, 2013) confirm that configurations of internal context factors such as firm age and intangible resource configurations, together with EO (content), influence firm growth. A number of authors (Delmar et al., 2003; McMahon, 2001; Steffens et al., 2009) relate these characteristics to small-firm growth.

Third, the organizational structure of small firms acts to motivate entrepreneurial activity. For example, Messersmith and Wales (2001) find that the growth effectiveness of EO in young high-technology firms is significantly enhanced through organizational commitment to developing supportive structures and high performance human resource systems. In addition, Meijaard et al. (2005) illustrate that organizational structures in small firms are more complex (nine cluster) than the Burns and Stalker (1961) representation of mechanistic versus organic structures. These studies demonstrate how firm context (external environment and internal structure, age and size) and content (EO) is related to small performance. However, few studies seem to address the process that small firms use to achieve different performance outcomes.

\section{Dimensions comprising an entrepreneurial configuration}

We used multiple domain configurations, which enabled us to examine complex multivariate relationships and establish the relative importance of fit among CCP dimensions. Our approach of including EO and strategy-making in addition to context variables allowed us to also study content and process dimensions.

The external and internal context drives the why of small-firm configurations. External environmental changes, especially competitive rivalry and related dynamism, strongly influence small-firm entrepreneurial actions (Antoncic and Hisrich, 2001; 
Miller, 1983). Dynamism refers to how small-firm owners/managers perceive the rate, unpredictability, and persistence of change in their markets and how these perceptions influence their decisions and behavior (Zahra, 1993). Their resultant behavior could become manifest in the type of opportunities they pursue and the strategies they develop (Smircich and Stubbart, 1985; Verreynne and Meyer, 2007; Zahra and Bogner, 1999). Such behavioral responses are characterized by risk-taking, pioneering behavior, and proactivity (Miller, 1983; Khandwalla, 1987). These responses are therefore linked to EO and strategy-making, as well as the internal context of the firm.

The internal context of the firm is reflected by its organizational structures, and firm age and size (Ketchen and Shook, 1996; Miller, 1986). Organizational structures generally evolve as firms move from start-up ventures to established enterprises, or from informal structures in the start-up phase to more formal, bureaucratic, organizational structures when more established (Burns and Stalker, 1961). Formal structures are characterized by specialized tasks, well-defined control and authority, and an established hierarchy. In contrast, informal structures are characterized by flexible administrative relations, one or few top managers (Mintzberg, 1979), and an emphasis on extensive personal interaction and face-toface communication that ensures collaboration (Morris and Kuratko, 2002). Informal structures have been strongly linked to entrepreneurial behaviors and processes in the literature (Lumpkin and Dess, 1996).

Firm age and size are widely used as control variables in multivariate studies of the EO-performance relationship, the logic being that younger and smaller firms will be more likely to exhibit a stronger EO (Covin and Covin, 1990). Hanks et al. (1993) shows that, as small-firms move through various stages of growth (changes in 
age and size), they change their structural configurations, management skills, and strategic priorities. Both the external context (reflected through dynamism) and the internal context (exhibited in organizational structure, firm age and size) align with the content and process of small-firm configurations.

The content of our small-firm configuration refers to the small firm's $E O$. EO reflects a firm's managerial philosophy and the content or nature of their strategic posture. Small firms with a high EO are characterized as being more innovative, proactive, risk-taking, and aggressive toward their competitors than firms with a lower EO (Lumpkin \& Dess, 1996). This strategic posture of the small firm can be placed on a continuum that ranges from conservative at the one extreme (low EO) to highly entrepreneurial (high EO) at the other (Barringer and Ireland, 2008; Miller, 1993). Firms with a high EO seem to function well in dynamic environments provided that they also use informal structures. In addition, the link between a high EO and firm performance has been well-established (e.g., Covin and Slevin, 1989; Lumpkin and Dess, 1996; Wiklund and Shepherd, 2005). This relationship seems to be significant and positive, with the strength of the relationship increasing over time (Rauch et al., 2009; Wiklund, 1999; Zahra and Bogner, 1999). EO facilitates the pursuit and exploitation of opportunities (Lumpkin and Dess, 1996), provided that EO is supported by the appropriate strategy-making processes.

Regarding process, we investigate the approach to strategy-making that a small firm uses. This has been identified by Dess et al. (1997) as an important aspect of configuration theory. Strategy-making processes that strengthen other aspects of a firm's configuration are essential; therefore, we include generative strategy-making. Identified by Hart (1991; 1992), the generative process describes an approach that encourages bottom-up idea-generation from other organizational members to 
recognize opportunities and set a strategic direction based on innovative activity, well-suited to the small-firm context (Verreynne and Meyer, 2007).

Last, it is important to relate the CCP approach to performance. Different small-firm configurations, such as clusters of firms in different stages of development, can still achieve satisfactory performance outcomes. To illustrate, Steffens et al. (2009) find that both young and old firms are likely to achieve sustained above-average performance should they focus on achieving above-average profitability. Performance is described in more detail in the methods section where it is correlated with the different configurations.

\section{Methods}

\section{Sample and Data}

A sample of 2000 New Zealand small firms was selected randomly from the Kompass commercial database. The selected firms excluded those with 100 or more employees, with farming operations, and foreign owned. Firms with 100 and more employees are considered large firms in New Zealand (Massey, 2005). Farming operations were excluded for two reasons: first, no database on these firms could be found; and second, comparable small-firm studies were not available, making a comparison of results challenging. Only firms that have their main operations in New Zealand were used in the sample, since our study did not focus on international entrepreneurship, but also to ensure a comparable sample. The questionnaire was mailed to the owner/manager of each small firm and a reminder was mailed one month later. A total of 504 questionnaires were returned of which 477 were deemed usable, leaving a response rate of 24 percent. The sizes of the firms measured by fulltime employee equivalents ranged from one to 99 . In line with previous research 
(Gray, 2004; O'Regan and Ghobadian, 2004), we only considered firms with at least ten full-time employees to ensure comparability with previous findings. This decision further reduced the sample size to 320 of the useable questionnaires. The 320 small firms were distributed across manufacturing (44\%), services $(25 \%)$, retail/wholesale $(16 \%)$ and construction (15\%). The majority of the firms were privately held companies $(71 \%)$. Twelve percent were owner-operated, eight percent were run as partnerships, and seven percent were public companies.

\section{Measures}

EO was measured using the scale developed by Covin and Slevin (1989), which consists of nine five-point items, with three items of each measuring innovativeness, pro-activeness and risk-taking. Covin and Slevin (1989) and Miller (1983, p. 79) explain that the items in this scale should be aggregated since EO can be viewed as a "basic, uni-dimensional strategic orientation". Two of these items had to be removed to ensure adequate fit statistics (Byrne, 2010). The remaining seven of the nine items were summed and presented as an index number, producing, according to Hair et al. (2010), good reliability with a Cronbach Alpha of 0.821 (see Table 2). A low index number represents a conservative approach to entrepreneurial endeavors, while a high index number represents a firm prone to frequent entrepreneurial actions (Miller and Friesen, 1978). Generative strategy-making (GSM) was measured with the scale developed by Dess et al. (1997), representing one of the four sub-scales of his strategy-making construct. Three five-point items that explain generative strategymaking, namely, "Most people in this organization are willing to take risks", "People in this organization are very dynamic and entrepreneurial" and "People are encouraged to experiment in this organization so as to identify new, more innovative 
approaches or products" were summed, divided by three, with the index number taken to present GSM. An alpha level of 0.70 or above is generally accepted (Nunnally, 1978) but, for research in new settings such as this, it can be reduced to 0.60 (Hair et al., 2010), and even as low as 0.50 (Nunnally, 1967).

Informality of structure (IS) was measured following the approach of Covin and Slevin (1989). The three items that most closely focused on the formal-informal continuum were used for this purpose. Respondents were asked to indicate on a seven-point Likert scale to what extent each item measured the collective management style of the firm. This resulted in an index with a Cronbach Alpha of .800 with a high value indicating an informal organizational structure while a low value indicates a formal organizational structure. Environmental dynamism (DYN) was assessed with the dynamism sub-scale developed by Khandwalla (1976/77). Respondents' ratings of four dynamism items were added to arrive at a single reliable index (Cronbach Alpha 0.818); the higher this index, the more dynamic a firm's environment. Firms with low dynamism indices operate in stable environments.

Finally, perceived performance was measured using the financial performance scale developed by Covin and Slevin (1989) and Gupta and Govindarajan (1984). It is often difficult to obtain data on small-firm financial performance such as profit levels, since New Zealand small firms are not obliged to publish their results and are often reluctant to provide financial information (Leitner and Guldenberg, 2010). Literature also shows a strong correlation between self-reported measures of performance and objective measures of performance (Covin and Slevin, 1988). Therefore, respondents had to indicate on a five-point Likert scale the "importance" of ten financial measures including sales level and growth, gross and net profit, return of equity and investment, and the ability to fund growth in the firm. Thereafter, they were asked to indicate 
their satisfaction with the firm's performance for the same ten performance measures. The "satisfaction" scores were multiplied by the "importance" scores and aggregated in order to compute a weighted average performance index for each firm. Weighting satisfaction with importance scores is the same method followed by Covin and Slevin. The higher the aggregate score on this relative index, the better the perceived firm performance.

\section{Description of scales}

Confirmatory factor analysis using AMOS version 20 was used to validate the EO, structure, environmental dynamism, and generative strategy-making scales and to test for discriminant validity with AMOS version 18 (see Table 2). The measurement model for EO described the data well $(\mathrm{GFI}=.961, \mathrm{AGFI}=.922, \mathrm{CFI}=.956, \mathrm{RMSEA}$ $=.08$ ). The measurement models for formal structure, generative strategy-making, and environmental dynamism were validated together because two of these constructs had only three items. These measurement models also described the data well (GFI $=$ $.957, \mathrm{AGFI}=.926, \mathrm{CFI}=.958, \mathrm{RMSEA}=.064)$. As shown by the bolded figures in Table 2, a test for discriminant validity showed that the correct items loaded most strongly only on their respective constructs, confirming that all the constructs were uniquely defined.

Insert Table II here

\section{Data-analysis}

All analyses were performed using IBM SPSS Statistics Version 20. A two-step cluster algorithm was used to construct small-firm clusters on the basis of EO, 
formality of structure, environmental dynamism, generative strategy-making, size and age. This first step in this process involves pre-clustering the firms into many small sub-clusters using a cluster feature tree, while the second step involves clustering the sub-clusters to create the final clusters. The method is described briefly below with more details given in Chiu et al. (2001) and Zhang et al. (1996).

The cluster feature tree consists of levels of nodes with a leaf representing a final sub-cluster. Each leaf is defined by the centroid of the above six variables for all the firms contained within it. Starting from the root node, each firm moves down the tree to the closest leaf entry as measured by the above six variables using a Euclidean distance. If the firm is within a given threshold distance of the leaf centroid, it is absorbed into the leaf and the centroid is updated. Otherwise, it breaks off on its own, creating a new leaf with a centroid defined by the values of the above six variables. In the second step, an agglomerative hierarchical cluster analysis is used to combine the sub-clusters into the final clusters. The Euclidean distances between all sub-clusters are compared with the closest pair of sub-clusters to be combined into a new subcluster. This process continues until the optimum number of clusters is obtained with the optimum defined using the Bayesian Information Criterion (BIC).

The resulting clusters were compared using their mean values for EO, formality of structure, environmental dynamism, generative strategy-making, size, and age. A chi-square test of association was used to test for differences between the clusters under the industry category while a Two Factor Between Subjects ANOVA test with Student-Newman-Keuls post hoc comparisons was used to compare the performance perceptions of the clusters while controlling for the industry sector.

\section{Results}


Scales were constructed for all four constructs; Table 3 shows the correlations between these scales together with the size of the firms (full-time equivalent employees [FTEs]) and their age measured in months. All the correlations were relatively weak but show that a high EO was more likely in dynamic environments and in firms with high generative strategy-making while generative strategy-making was higher in firms with more informal structures and in environments that were more dynamic. Finally EO appears to be weaker in older firms.

Insert Table III here

Three clusters were created using the two-stage clustering with confirmation for the number of clusters provided by a hierarchical clustering using Ward's method to measure the distance between clusters. Table 4 provides profiles for these three clusters showing how they differ in terms of the clustering variables. We named the first cluster consisting of young, formal firms with high EO as Young Corporates. The second and largest cluster consists of young, informal firms with moderate EO, which we called Young Simple firms. Finally, because the third and smallest cluster consists of older firms with moderate EO and a mix of more informal and more formal firms, we labeled it Mature Consolidators. Clearly, there are also significant differences in firm size for these clusters with firms from the Young Simple cluster having both the smallest size and the lowest level of GSM on average, while firms from the Young Corporates were the largest on average, despite being the youngest firms on average. 


\section{Insert Table IV here}

There were significant associations between the industry categories and the clusters (Chi-Square Likelihood Ratio $=13.23, \mathrm{df}=6, \mathrm{p}=.040$; see Table 5). The Young Corporates and Young Simple firms were relatively common in the services industry, while Mature Consolidators were relatively uncommon in this industry. In the manufacturing sector, Young Simple firms were most common. The Mature Consolidators were relatively uncommon in the construction industry while the Young Simple firms were relatively common. Finally, Young Corporates and Mature Consolidator firms were relatively uncommon in the retail/wholesale industry while Young Simple firms were relatively common.

\section{Insert Table V here}

Studies such as that of McGahan and Porter (1997) suggest that performance varies between industry categories. They found that 19 percent of the variation in profitability could be explained by industry sector. This means that performance between the clusters can only be compared if we control for industry category. A twofactor analysis shows no significant interaction effect $(\mathrm{F}(6,308)=1.20, \mathrm{p}=.308)$, suggesting that the cluster effect is similar within each industry category. However, there are small but significant differences in performance across industry sectors $(\mathrm{F}(3,308)=3.98, \mathrm{p}=.008$, partial eta squared $=.037)$ and across clusters $(\mathrm{F}(2,308)=$ $3.53, \mathrm{p}=.030$, partial eta squared $=.022$ ). As indicated in Table 6 , the marginal means and Student-Neuman-Keuls Post Hoc tests show that, when controlling for industry sector, the Young Corporate cluster with high EO have significantly higher 
perceptions of their performance than the Young Simple cluster with lower EO. However, the perceptions of the Mature Consolidator cluster of established moderate EO firms lie in between these extremes with no significant difference between Clusters 1 and 3 or between Clusters 2 and 3. The results indicate that Young Simple firms would not perform well while Young Corporates would. However, results show no support for strong performance by Mature Consolidators because their performance was not found to be significantly better than that of the Young Simple firms.

Insert Table VI here

It should also be mentioned that the major differences between the industry sectors occur only in the case of the retail/wholesale sector. As shown in Table 7, performance is significantly higher for this sector than for any of the other sectors when we look inside each cluster.

Insert Table VII here

\section{Discussion}

This article developed contemporary entrepreneurial configurations of small firms and related these to performance. We used the CCP framework to structure our cluster variables, thereby adding a process dimension of generative strategy-making to the more common taxonomies found in the literature, incorporating content (EO) and context (external environment and internal structure). Our analysis identified 
three configurations of small firms, each with a unique alignment of the CCP dimensions, as shown in Table 8 .

Insert Table VIII here

The three clusters we identified were Young Corporates (Cluster 1), Young Simple (Cluster 2) and Mature Consolidators (Cluster 3). Young Corporates tended to have a high EO and used generative strategy-making within dynamic environments. While this was expected, the large average size and use of formal systems and structures at such an early stage was not. Chi-square tests indicated that this configuration of firms was more common in the service industry and unlikely to be found in the retail/wholesale industry. After controlling for industry, this cluster was significantly more successful than the other two clusters. Similar to Hanks et al., (1993), we therefore showed that formal structures are needed to enable growing firms to operate more efficiently and effectively. Formalization facilitates the professionalization of firms' managerial capabilities, thus supporting higher levels of performance. Especially in the services and manufacturing sector, where rivalry is intense, formality is needed for two reasons: first, to compete effectively by taking advantage of emerging opportunities and thus support the enabling role of an organizational structure for $\mathrm{EO}$; and second, to relate these two dimensions to performance (Messersmith and Wales, 2001). The technological environment encountered by these firms also places higher demands on manufacturing and service businesses to adopt formal systems like CRM and those related to accounting, which are more freely available at a lower cost to small businesses today. Despite arguments that informal organizational structures facilitate communication (Gibbons and 
O’Connor, 2005), which strengthens entrepreneurship, our results suggest two alternatives: first, that deliberate and formal interaction and mutual adjustment underlie EO and generative strategy-making; and second, that firms with formal structures use more systematic processes. These findings questions the thinking about organizational structure as it applies to the EO relationship in young, small firms. In addition, these firms used bottom-up idea generation from professional, empowered organizational members who feel part of the business, despite their short tenure and contribution towards the existing EO, as generative strategy-making literature indicates (Verreynne and Meyer, 2007).

Young Simple firms exhibited a conservative approach to entrepreneurial behaviors with moderate EO, informal simple structures, lower generative strategy making, and the capacity to operate in relatively stable environments. The performance level of this configuration was low when compared to the two other clusters. Young Simple firms were more common in the construction industry. This configuration indicates a strong leader driving the firm's strategy and using their personality and power within a simple structure characterized by centralized decisionmaking and little generative strategy-making. This is typical of early-stage firms (Hanks et al., 1993). Although these firms have the potential to grow their capacities, the vulnerability of this configuration is shown even in stable environments. It can be argued that survival over a prolonged period in more dynamic environments would be unlikely for these firms.

Mature Consolidators were older, but also showing moderate EO and generative strategy-making, coupled with informal structures in moderately dynamic environments. This configuration was associated with average performance. Firms in this cluster appear to be similar to Borsch et al.'s (1999) managerial small firms, 
suggesting a balance of exploration with exploitation strategies, thus resulting in a moderate EO. To facilitate this strategy, the organizational structure balanced formality with informality. Similar to Hanks et al. (1993), we found that these firms were in in the mature stages of the life-cycle in moderately dynamic environments.

Our findings contribute to the academic debate in three ways. First, we empirically verified three clusters of small firms namely Young Corporates, Young Simple and Mature Consolidators. Depending on the configuration of CCP dimensions, we showed that these clusters of firms had varying performance levels. Second, we demonstrated that small-firm configurations are complex phenomena. By adding generative strategy-making to our configuration dimensions and by using the CCP approach, our clusters go beyond the context and content dimensions to show the importance of aligning process needs with these aspects. The interplay of all three dimensions suggests that perceived performance is not merely a function of strategy or product, but an intricate alignment of dimensions. In this regard, it would be unrealistic for imitator firms to copy the strategy and entrepreneurial posture of market leaders within their industry, since a complex set of factors determines a small firm's configuration and therefore performance. Third, we contribute by finding evidence of the role of early formalization aligned with generative strategy-making and EO, which enable young firms to grow quickly. This Young Corporates configuration provides insight into how these firms reap performance benefits. Future research can use these findings to track how configurations, particularly their relationship with performance, change over time to best deal with the challenges facing small firms.

Our findings also have implications for practice. Early stage venture start-ups may benefit from this study because it shows that founders should develop a holistic 
view of their business and nurture their firm's strategic orientation to align with processes, structure and the environment. Skilled organizational members who are loyal may find it beneficial to stay with a young firm, contribute ideas, and be willing to pursue opportunities that benefit the firm and themselves. In addition, small firms should embrace formal structures early on, allowing them to exploit opportunities in dynamic environments and reap performance benefits.

More widely, our results also have implications for educators and policymakers. Education and training programs should take care to emphasize that small firms should align key configuration dimensions to enhance their ability to fully utilize early entrepreneurial competencies. Furthermore, the value of early formalization and participation in strategy-making should be accentuated.

A number of limitations need to be kept in mind when interpreting the results of this study. First, the aspects of an entrepreneurial configuration in the framework suggested in this article are comprehensive, but certainly not exhaustive. Second, whereas the cross-sectional design may be a limitation, no claims about a causal effect on performance were made. Instead, clusters were examined to indicate if certain configurations are associated with better performance. That said, future research could benefit from longitudinal designs to track the changes in configurations as well as their performance over time. Third, this study also used selfreporting measures (Covin et al., 2006). An owner/manager who views his/her firm as entrepreneurial is thus likely to match his/her actions to that perception as well as the strategy-making process. To overcome this bias, scales, which were worded neutrally, were used in this study. In particular, scales with positive extremes were used in the case of EO. For instance, in one of these items "A strong emphasis on R\&D, technological leadership and innovation" was contrasted with "A strong 
emphasis on the marketing of tried and true products and services", while "High risk projects with chances of very high returns" were contrasted with "Low-risk projects with normal and certain rates of return." Fourth, while many configuration articles in the past were primarily inductive in nature (Dess et al., 1993), this article is based on deductive research. This is a natural progression of the field, where theories were built inductively and then tested. It is acknowledged, however, that configurations are inherently multidimensional entities in which key attributes are tightly inter-related and mutually reinforcing. A primary task is to disentangle complex relationships by isolating and specifying key constructs based on the literature (Dess et al., 1993, p. 784). Fifth, we note the effects of data aggregation. Configuration studies use aggregated data, resulting in a loss of the "richness" of meaning (Weick, 1979). However, this approach also leads to dimension reduction, which may enhance analysis and interpretation.

\section{Conclusion}

To summarize, our study illustrates the value of taking an entrepreneurial configuration approach for small firms. Instead of merely focusing on the environmental context and EO and relating these to performance, our configurations show how context (environmental factors and internal structure, firm age and size), content (EO) and process (GSM) are aligned and related to perceived firm performance. While our findings are generally consistent with other studies using context and content, the process element provides more in-depth insight into how the process works inside the small firm. Our three clusters of Young Corporates, Young Simple and Mature Consolidators emphasize the benefits of early formalization of systems and structures, a high EO, and using generative strategy-making. This calls 
into question the argument that informal structures support entrepreneurial behavior in firms. Our findings reinforce the importance of this line of enquiry, which can benefit from longitudinal research design. In addition, capturing firm exits can clarify if small firms that exit do so based on a focused plan, or misaligned configuration. 


\section{References}

Andersén, J. (2012), "A resource-based taxonomy of manufacturing MSMEs", International Journal of Entrepreneurial Behaviour and Research, Vol. 18 No. 1, pp. 98-122.

Anderson, B.S. \& Eshima, Y. (2013), "The influence of firm age and intangible resources on the relationship between entrepreneurial orientation and firm growth among Japanese SMEs", Journal of Business Venturing, Vol. 28 No. 3, pp. 413-429.

Antoncic, B. and Hisrich, R.D. (2001), "Intrapreneurship: construct refinement and cross-cultural validation", Journal of Business Venturing, Vol. 16 No. 5, pp. 495-527.

Aragon-Sanchez, A. and Sanchez-Marin, G, (2005), "Strategic orientation, management characteristics, and performance: a study of Spanish SMEs", Journal of Small Business Management, Vol. 43 No. 3, pp. 287-309.

Bantel, K.A. (1998), "Technology-based, adolescent firm configurations: strategy identification, context, and performance", Journal of Business Venturing, Vol. 13 No. 3, pp. 205-230.

Barringer, B.R. and Ireland D.R. (2008), Entrepreneurship: Successfully Launching New Ventures, Pearson Prentice Hall, Upper Saddle River, NJ.

Borsch, O.J., Huse, M. and Senneseth, K. (1999), "Resource configurations, competitive strategies, and corporate entrepreneurship: an empirical examination of small firms", Entrepreneurship Theory \& Practice, Vol. 24 No. 1, pp. 49-70.

Burgelman, R.A. (1983), "Corporate entrepreneurship and strategic management: Insights from a process study", Management Science, Vol. 29 No. 12, pp. 1349-1351.

Burns, T. and Stalker, G.M. (1961), The Management of Innovation, Tavistock, London.

Byrne, B.M. (2010), Structural Equation Modeling with AMOS: Basic Concepts, Applications and Programming, $2^{\text {nd }}$ ed., Routledge, New York.

Chiu, T., Fang, D., Chen, J., Wang, Y. and Jeris, C. (2001), "A robust and scalable clustering algorithm for mixed type attributes in large database environment", in Proceedings of the seventh ACM SIGKDD international conference on knowledge discovery and data mining, ACM, San Francisco, CA, pp. 263-268.

Covin, J.G. and Covin, T.J. (1990), "Competitive aggressiveness, environmental context, and small firm performance", Entrepreneurship Theory and Practice, Vol. 14 No. 4, pp. 35-50.

Covin, J.G. and Slevin, D.P. (1988), "The influence of organization structure on the utility of an entrepreneurial top management style", Journal of Management Studies, Vol. 25 No. 3, pp. 217-234.

Covin, J.G. and Slevin, D.P. (1989), "Strategic management of small firms in hostile and benign environments", Strategic Management Journal, Vol. 10 No. 1, pp. $75-87$.

Covin, J.G., Green, K.M. and Slevin, D.P. (2006), "Strategic process effects on the entrepreneurial orientation-sales growth rate relationship", Entrepreneurship: Theory \& Practice, Vol. 30 No. 1, pp. 57-81.

Delmar, F., Davidsson, P. \& Gartner, W.B. (2003), "Arriving at the high-growth firm”, Journal of Business Venturing, Vol. 18 No. 2, pp. 189-216.

Dess, G.G., Ireland, R.D., Zahra, S.A., Floyd, S.W., Janney, J.J. \& Lane, P.J. (2003), 
"Emerging issues in corporate entrepreneurship", Journal of Management, Vol. 29 No. 3, pp. 351-378.

Dess, G.G., Lumpkin, G.T. and Covin, J.G. (1997), "Entrepreneurial strategy-making and firm performance: tests of contingency and configurational models", Strategic Management Journal, Vol. 18 No. 9, pp. 677-695.

Dess, G.D., Newport, S. and Rasheed, A.M.A. (1993), "Configuration research in strategic management: Key issues and suggestions", Journal of Management, Vol. 19 No. 4, pp. 775-795.

Doty, D.H., Glick, W.H. and Huber, G.P. (1993), "Fit, equifinality and organizational effectiveness: a test of two configurational theories", Academy of Management Journal, Vol. 36 No. 6, pp. 1196-1250.

Gibbons, P.T. and O'Connor, T. (2005), "Influences on strategic planning processes among Irish SMEs", Journal of Small Business Management, Vol. 43 No. 2, pp. 170-186.

Gibb, A. and Li, J. (2003), “Organizing for enterprise in China: what can we learn from the Chinese micro, small and medium enterprise development experience", Futures, Vol. 35 No 4, pp. 403-421.

Gray, C. (2004), "Management development in European small and medium enterprises", Advances in Developing Human Resources, Vol. 6 No. 4, pp. 451469.

Green, K.M., Covin, J.G. \& Slevin, D.P. (2008), "Exploring the relationship between strategic reactiveness and entrepreneurial orientation: the role of structure-style fit", Journal of Business Venturing, Vol. 23, No. 3, pp. 356-383.

Greiner, L.E. (1972), "Evolution and revolution as organizations grow", Harvard Business Review, Vol. 50 No. 4, pp. 37-46.

Gupta, A.K. and Govindarajan, V. (1984), "Business unit strategy, managerial characteristics, and business unit effectiveness at strategy implementation", Academy of Management Journal, Vol. 27 No. 1, pp. 25-41.

Hair, J.F., Black, W.C., Babin, B.J., Anderson, R.E. and Tatham, R.L. (2010), Multivariate Data Analysis, $7^{\text {th }}$ ed., Prentice Hall, Upper Saddle River, NJ.

Hakala, H. and Kohtamäki, M. (2011), "Configurations of entrepreneurial- customerand technology orientation: differences in learning and performance of software companies", International Journal of Entrepreneurial Behaviour and Research, Vol. 17 No. 1, pp. 64-81.

Hambrick, D.C. (2003), "On the staying power of defenders, analyzers, and prospectors", The Academy of Management Executive, Vol. 17 No. 4, pp. 115118.

Hanks, S.H., Watson, C.J., Jansen, E. and Chandler, G.N. (1993), "Tightening the life-cycle construct: a taxonomic study of growth stage configurations in hightechnology organizations", Entrepreneurship Theory \& Practice, Vol.18 No. 2, pp. 5-29.

Hart, S.L. (1991), "Intentionality and autonomy in strategy-making process: modes, archetypes, and firm performance", in Shrivastava, P., Huff, A. and Dutton, J. (Eds), Advances in Strategic Management, JAI Press, Greenwich, Vol. 7 No. 3, pp. $97-127$.

Hart, S.L. (1992), “An integrative framework for strategy-making processes”, Academy of Management Review, Vol.17 No. 2, pp. 327-351.

Ketchen D.J. Jr. and Shook, C.L. (1996), “The application of cluster analysis in strategic management research: Analysis and critique", Strategic Management Journal, Vol. 17 No. 6, pp. 441-458. 
Ketchen, D.J. Jr., Thomas, J.B. and Snow, C.C. (1993), “Organizational configurations and performance: a comparison of theoretical approaches", Journal of Management, Vol. 36 No. 6, pp. 1278-1313.

Khandwalla, P.N. (1976/77), "Some top management styles, their context and performance", Organization and Administrative Sciences, Vol. 7 No. 4, pp. 21 51 .

Khandwalla, P.N. (1987), "Generators of pioneering-innovative management: some Indian evidence”, Organization Studies, Vol. 7 No. 4, pp. 21-51.

Lee, K.S., Lim, G.H. \& Tan, S.J. (1999), "Dealing with resource disadvantage: generic strategies for SMEs”, Small Business Economics, Vol. 12 No. 4, pp. 299-311.

Leitner, K.H. \& Güldenberg, S. (2010), "Generic strategies and firm performance in SMEs: a longitudinal study of Austrian SMEs", Small Business Economics, Vol. 35 No. 2, pp. 169-189.

Lumpkin, G.T. and Dess, G.G. (1996), "Clarifying the entrepreneurial orientation construct and linking it to performance", The Academy of Management Review, Vol. 21 No. 1, pp. 135-154.

Massey, C. (Ed.), (2005), Entrepreneurship and Small Business Management in New Zealand, Pearson-Prentice-Hall, New Zealand.

McCann, J.E. III, Leon-Guerrero, A.Y. and Haley, J.D.J. (2001), "Strategic goals and practices of innovative family businesses", Journal of Small Business Management, Vol. 39 No. 1, pp. 50-59.

McGahan, A.M. and Porter, M.E. (1997), "How much does industry matter, really?", Strategic Management Journal, Vol. 18, Summer, pp. 15-30.

McMahon, R.G.P. (2001), "Deriving an empirical development taxonomy for manufacturing SMEs using data from Australia's business longitudinal survey", Small Business Economics, Vol. 17 No. 3, pp. 197-212.

Meijaard, J., Brand, M.J. \& Mosselman, M. (2005), "Organizational structure and performance in Dutch small firms", Small Business Economics, Vol. 25 No. 1, pp. 83-96.

Messersmith, J.G. \& Wales, W.J. (2013), "Entrepreneurial orientation and performance in young firms: the role of human resource management", International Small Business Journal, Vol. 31 No. 2, pp. 115-136.

Miles, R.E. and Snow, C.C. (1978), Organizational, Strategy, Structure, and Process, McGraw Hill, New York, NY.

Miller, D. (1983), "The correlates of entrepreneurship in three types of firms", Management Science, Vol. 29 No. 7, pp. 770-791.

Miller, D. (1986), "Configurations of strategy and structure: toward a synthesis", Strategic Management Journal, Vol. 7 No. 3, pp. 233-249.

Miller, D. (1987), "Strategy-making and structure: analysis and implications for performance", Academy of Management Journal, Vol. 30 No. 1, pp. 7-32.

Miller, D. (1988), "Relating Porter's business strategies to environment and structure: analysis and performance implications", Academy of Management Journal, Vol. 31 No. 2, pp. 280-308.

Miller, D. (1993), "The architecture of simplicity", Academy of Management Review, Vol. 18 No. 1, pp. 116-138.

Miller, D. and Friesen, P.H. (1978), "Archetypes of strategy formulation", Management Science, Vol. 24 No. 9, pp. 921-933.

Miller D. and Friesen, P.H. (1984), Organizations: A Quantum View, Prentice Hall, Englewood Cliffs, NJ. 
Mintzberg, H. (1979), The Structuring of Organization: A Synthesis of Research, Prentice Hall, Englewood Cliffs, NJ.

Morris, M.H. and Kuratko, D.F. (2002), Corporate Entrepreneurship:

Entrepreneurial Development within Organizations, Harcourt, Fort Worth, TX.

Murimbika, M. and Urban, B. (2013), "Strategic management practices and corporate entrepreneurship: a cluster analysis of financial and business services firms in South Africa", African Journal of Business Management, Vol. 7 No. 16, pp. $1522-1535$.

Ng, W. \& Keasey, K. (2010), "Growing beyond smallness: how do small, closely controlled firms survive?", International Small Business Journal, Vol. 28 No. 6, pp. 620-630.

Nunnally, J.C. (1967), Psychometric theory, McGraw-Hill, New York.

Nunnally, J.C. (1978), Psychometric Theory, $2^{\text {nd }}$ ed., McGraw-Hill, New York.

O'Regan N. and Ghobadian, A. (2004), "Testing the homogeneity of SMEs: the impact of size on managerial and organisational processes", European Business Review, Vol. 16 No. 1, pp. 64-79.

Payne, G.T., Kennedy, K.H. and Davis J.L. (2009), "Competitive dynamics among service SMEs”, Journal of Small Business Development, Vol. 47 No. 4, pp. 421-442.

Pettigrew, A.M. 1987. "Context and action in the transformation of the firm", Journal of Management Studies, Vol. 24, pp. 649-670.

Porter, M.E. (1980), Competitive Strategy: Techniques for Analyzing Industries and Competitors, The Free Press, New York, NY.

Rauch A., Wiklund J., Lumpkin, G.T. and Frese M. (2009), "Entrepreneurial orientation and business performance: an assessment of past research and suggestions for the future", Entrepreneurship Theory and Practice, Vol. 33 No. 3, pp. 761-787.

Regnér, P. (2003), "Strategy creation in the periphery: inductive versus deductive strategy making", Journal of Management Studies, Vol. 40, pp. 57-82.

Rosenbusch, N., Brinckman, J. and Raushc, A. (2011), "Is innovation always beneficial? A meta-analysis of the relationship between innovation and performance in SMEs", Journal of Business Venturing, Vol. 26 No. 4, pp. 441457.

Short, J.C., Payne, G.T. and Ketchen, D.J. (2008), "Research on organizational configurations: past accomplishments and future challenges", Journal of Management, Vol. 34 No. 6, pp. 1053-1079.

Smircich, L. and Stubbart C. (1985), "Strategic management in an enacted world", Academy of Management Review, Vol. 10 No. 4, pp. 724-736.

Snow, C.C., Miles, R.E. and Miles, G. (2005), "A configurational approach to the integration of strategy and organization research", Strategic Organization, Vol. 3 No. 4, pp. 431-439.

Steffens, P., Davidsson, P. and Fitzsimmons, J. (2009), "Performance configurations over time: Implications for growth- and profit-oriented strategies", Entrepreneurship Theory and Practice, Vol. 33 No. 1, pp. 125-148.

Verreynne, M.L. and Meyer, D. (2007), "Modeling the role of intrapreneurial strategy-making in small firm performance", in Lumpkin, T. and Katz, J. (Eds), Entrepreneurial Strategic Processes - Advances in Entrepreneurship, Firm Emergence and Growth, Elsevier, Amsterdam, Vol. 10, pp. 103-130. 
Verreynne, M. \& Meyer, D. (2011), "Differentiation strategies in mature small firms - the impact of uncertain environments", International Journal of Entrepreneurship and Small Business, Vol. 12 No. 3, pp. 327-342

Wagner, E.R. and Hansen, E.N. (2005), "Innovation in large versus small companies: insights from the US wood products industry", Management Decision, Vol. 43 No. 6, pp. 837-850

Weick, K.E. (1979), "Cognitive Processes in Organizations”, Research in Organizational Behaviour, Vol. 1 No. 1, pp. 41-74.

Wiklund, J. (1999), "The sustainability of the entrepreneurial orientation-performance relationship", Entrepreneurship Theory \& Practice, Vol. 24 No. 1, pp. 37-48.

Wiklund, J. and Shepherd, D.A. (2005), "Entrepreneurial Orientation and small business performance: a configurational approach", Journal of Business Venturing, Vol. 20 No. 1, pp. 71-91.

Zahra, S.A. (1993), "Environment, corporate entrepreneurship and company performance: a taxonomic approach", Journal of Business Venturing, Vol. 8 No. 4, pp. 319-340.

Zahra, S.A. and Bogner, W.C. (1999), "Technology strategy and software new ventures' performance: exploring the moderating effect of the competitive environment", Journal of Business Venturing, Vol. 15 No. 2, pp. 135-173.

Zahra, S. and George, G. (1999), "Manufacturing strategy and new venture performance: a comparison of independent and corporate ventures in the biotechnology industry", Journal of High Technology Management Research, Vol. 10 No. 2, pp. 313-345

Zhang, T., Ramakrishnon, R. and Livny, M. (1996), "BIRCH: An efficient data clustering method for very large databases", in Proceedings of the ACM SIGMOD Conference on Management of Data, ACM, Montreal, Canada, Vol. 25 No. 2, pp. 103-114. 
Table I: Small Firm Configurations from the Literature

\begin{tabular}{|c|c|c|c|c|}
\hline Author & Journal & Configuration (or classification) & Sample & Dimensions in configuration \\
\hline $\begin{array}{l}\text { Borsch et al } \\
(1999)\end{array}$ & ETP & $\begin{array}{l}\text { 1. Managerial firm (analyzers, use market strategies) } \\
\text { 2. Technological firm (prospectors, used product and growth strategies) } \\
\text { 3. Traditional firm (avoided growth or risk-taking) } \\
\text { 4. Impoverished firm (stuck in the middle) }\end{array}$ & $\begin{array}{l}660 \text { senior } \\
\text { managers of } \\
\text { small Swedish } \\
\text { firms }\end{array}$ & $\begin{array}{l}\text { Strategic posture ( } 4 \text { strategies), competitive } \\
\text { strategies, age, size by employees, industry, } \\
\text { resources (human resources [education, } \\
\text { experience], social [networks], } \\
\text { organizational resources [structure], } \\
\text { technological resources, finance, } \\
\text { geographical location) }\end{array}$ \\
\hline $\begin{array}{l}\text { Wiklund \& } \\
\text { Shepherd } \\
(2005)\end{array}$ & JBV & $\begin{array}{l}\text { 1. Stable environment, low access to capital, high EO, high performance; } \\
\text { 2. Stable environment, high access to capital, high EO, high performance (lower than } \\
\text { cluster 1), } \\
\text { 3. Dynamic environment, low access to capital mod performance, high EO; } \\
\text { 4. Dynamic environment, high access to capital, high EO, lowest performance }\end{array}$ & $\begin{array}{l}413 \text { Swedish } \\
\text { small businesses }\end{array}$ & $\begin{array}{l}\text { Small business performance (combined self- } \\
\text { reported performance and growth), EO, } \\
\text { perceived access to financial capital, } \\
\text { perceived dynamism }\end{array}$ \\
\hline $\begin{array}{l}\text { Hakala and } \\
\text { Kohtamäki } \\
(2011)\end{array}$ & IJEBR & $\begin{array}{ll}\text { 1. } & \text { Servants } \\
\text { 2. } & \text { Players } \\
\text { 3. } & \text { Integrators }\end{array}$ & $\begin{array}{l}164 \text { Finnish } \\
\text { software } \\
\text { companies }\end{array}$ & $\begin{array}{l}\text { Strategic orientations (EO, marketing and } \\
\text { technological orientation), organizational } \\
\text { learning and performance (self-reported) }\end{array}$ \\
\hline $\begin{array}{l}\text { Hanks et al., } \\
1993\end{array}$ & ETP & $\begin{array}{l}\text { 1. Start-up: Young, small firms, centralized and informal; high-growth, focused on } \\
\text { R\&D, product development; } \\
\text { 2. Expansion: slightly older and bigger, highest sales \& employment growth, } \\
\text { centralized, more formal org structure, more specialized functions. } \\
\text { 3. Later expansion/early maturity - slightly younger than B, but larger — rapid } \\
\text { growth; } \\
\text { 4. Maturity/diversification - older firms, larger, more decentralized and formal } \\
\text { structures. } \\
\text { 5. E\&F: older, smaller firms, do not follow life-cycle model }\end{array}$ & $\begin{array}{l}133 \text { High-tech } \\
\text { Utah firms; } \\
\text { average } \\
\text { employees = } \\
125 \text { (large } \\
\text { employee size } \\
\text { range) }\end{array}$ & $\begin{array}{l}\text { Age, size, growth rate (employee \& sales } \\
\text { growth) = VLC } \\
\text { Structural variables = vertical differentiation, } \\
\text { structural form, formalization, specialization, } \\
\text { and centralization. total sales, sales growth, } \\
\text { total employees, employee growth. }\end{array}$ \\
\hline $\begin{array}{l}\text { Anderson \& } \\
\text { Eshima } \\
(2013)\end{array}$ & & $\begin{array}{l}\text { Unnamed - } 4 \text { cluster groups: } \\
\text { 1. Younger firm, low intangible resources, low EO, little growth; } \\
\text { 2. Younger firm, high EO, high intangible resources, higher growth; } \\
\text { 3. Older firm, low intangible resources, low EO, slightly higher growth than cluster 1; } \\
\text { 4. 4. Older firm, moderate EO, high intangible resources, stable (limited) firm growth }\end{array}$ & $\begin{array}{l}\text { 230 Japanese } \\
\text { SMEs (Average } \\
\text { employee size }= \\
\text { 37; Mean age }= \\
\text { 28) }\end{array}$ & $\begin{array}{l}\text { Age, Intangible resources, EO -firm growth, } \\
\text { sales turnover, market scope, industry } \\
\text { (technical services \& manufacturing) }\end{array}$ \\
\hline $\begin{array}{l}\text { Delmar et al } \\
(2003)\end{array}$ & JBV & $\begin{array}{l}\text { 1. Super absolute growers, } \\
\text { 2. Steady sales growers, } \\
\text { 3. Acquisition growers, } \\
\text { 4. Super relative growers, }\end{array}$ & $\begin{array}{l}1501 \text { high } \\
\text { growth Swedish } \\
\text { firms with more } \\
\text { than } 20\end{array}$ & $\begin{array}{l}\text { Firm size, firm age, industry, various growth } \\
\text { measures (average growth rate, regularity of } \\
\text { growth, duration of growth, dominant type of } \\
\text { growth) }\end{array}$ \\
\hline
\end{tabular}




\begin{tabular}{|c|c|c|c|c|}
\hline & & $\begin{array}{ll}\text { 5. } & \text { Erratic one-shot growers, } \\
\text { 6. Employment growers, } \\
\text { 7. } & \text { Steady overall growers }\end{array}$ & employees & \\
\hline $\begin{array}{l}\text { McMahon } \\
\text { (2001) }\end{array}$ & SBE & $\begin{array}{ll}\text { 1. } & \text { Low-growth (lifestyle) pathway; } \\
\text { 2. } & \text { High-growth (entrepreneurial) pathway; } \\
\text { 3. } & \text { Moderate (capped) growth pathway }\end{array}$ & $\begin{array}{l}2413 \text { Australian } \\
\text { manufacturing } \\
\text { SMEs }\end{array}$ & Age, size, growth rate \\
\hline $\begin{array}{l}\text { Steffens et } \\
\text { al., (2009) }\end{array}$ & ETP & $\begin{array}{ll}\text { 1. } & \text { Poor } \\
\text { 2. } & \text { Low profit } \\
\text { 3. } & \text { Low growth } \\
\text { 4. } & \text { Growth focus } \\
\text { 5. Profit focus } \\
\text { 6. } \\
\text { 7. } & \text { High growth } \\
\text { 8. } & \text { High profit } \\
\text { 9. } & \text { Star }\end{array}$ & $\begin{array}{l}\text { 2622 Australian } \\
\text { ABS data - } \\
\text { firms less than } \\
200 \text { employees, } \\
\text { various } \\
\text { industries, } \\
\text { longitudinal }\end{array}$ & Sales growth, pretax ROA, firm age \\
\hline $\begin{array}{l}\text { Messersmith } \\
\& \text { Wales } \\
(2011)\end{array}$ & ISBJ & $\begin{array}{l}\text { Main finding: Growth effectiveness of EO in young high-tech firms is significantly } \\
\text { enhanced through org commitment to the development of HPWS \& partnership } \\
\text { philosophy } \\
\text { Not identified clusters, but interaction effects: } \\
\text { 1. Low high performance work systems (HPWS), low EO, low partnership, low sales } \\
\text { growth; } \\
\text { 2. High EO, low HPWS, low partnership, sales growth - rank 2; } \\
\text { 3. High HPWS, low EO, high partnership, lower sales growth (rank 2); } \\
\text { 4. High HPWS, high EO, high partnership, high sales growth }\end{array}$ & $\begin{array}{l}119 \text { NETS } \\
\text { young high tech } \\
\text { small firms in } \\
\text { USA (less than } \\
10 \text { years) }\end{array}$ & $\begin{array}{l}\text { EO, high performance work systems (HPWS } \\
\text { - HRM systems), partnership philosophy, } \\
\text { firms sales growth. Controls: firm size, firm } \\
\text { age, ownership structure \& industry } \\
\text { classification }\end{array}$ \\
\hline $\begin{array}{l}\text { Meijaard, } \\
\text { Brand \& } \\
\text { Mosselman } \\
(2005)\end{array}$ & SBE & $\begin{array}{ll}\text { Nine org structure typologies: } \\
\text { 1. Entrepreneur with submissive team; } \\
\text { 2. Co-working boss with open structure; } \\
\text { 3. Entrepreneurial Team } \\
\text { 4. Boss - loose control; } \\
\text { 5. Boss - tight control } \\
\text { 6. Singular structure; } \\
\text { 7. U-form; } \\
\text { 8. Matrix organisation } \\
\text { 9. M-form }\end{array}$ & $\begin{array}{l}1411 \text { small } \\
\text { Dutch firms } \\
\text { (100 employees } \\
\text { or less) }\end{array}$ & $\begin{array}{l}\text { Organizational structure and firm } \\
\text { performance (sales } \\
\text { growth, profitability and innovativeness) }\end{array}$ \\
\hline
\end{tabular}


Table II.

Imputed Correlations for Constructs

\begin{tabular}{|c|c|c|c|c|}
\hline & DYN & IS & GSM & EO \\
\hline $\begin{array}{l}\text { The nature of competition varies a great deal from one line } \\
\text { to another }\end{array}$ & .856 & .107 & .144 & .362 \\
\hline $\begin{array}{l}\text { Market dynamism and uncertainty vary a great deal from } \\
\text { one line to another }\end{array}$ & .815 & .102 & .138 & .345 \\
\hline $\begin{array}{l}\text { We are a highly diversified firm and operate in unrelated } \\
\text { industries }\end{array}$ & .519 & .065 & .088 & .220 \\
\hline $\begin{array}{l}\text { Customer buying habits vary a great deal from one line to } \\
\text { another }\end{array}$ & .744 & .093 & .126 & .315 \\
\hline $\begin{array}{l}\text { A strong emphasis on getting things done even if this } \\
\text { means disregarding formal procedures }\end{array}$ & .101 & .806 & .180 & .106 \\
\hline $\begin{array}{l}\text { Loose, informal control; heavy dependence on informal } \\
\text { relationships and norm of co-operation for getting work } \\
\text { done }\end{array}$ & .091 & .727 & .162 & .095 \\
\hline $\begin{array}{l}\text { A strong tendency to get the requirements of the situation } \\
\text { and the individual's personality define proper on-job } \\
\text { behavior }\end{array}$ & .092 & .735 & .164 & .096 \\
\hline People in this firm are very dynamic and entrepreneurial & .133 & .176 & .787 & .419 \\
\hline $\begin{array}{l}\text { People are encouraged to experiment in this firm so as to } \\
\text { identify new, more innovative approaches or products }\end{array}$ & .071 & .094 & .421 & .224 \\
\hline Most people in this firm are willing to take risks & .108 & .143 & .642 & .342 \\
\hline $\begin{array}{l}\text { Typically adopts a bold, aggressive posture in order to } \\
\text { maximize the probability of exploiting potential } \\
\text { opportunities }\end{array}$ & .294 & .091 & .370 & .695 \\
\hline $\begin{array}{l}\text { Owing to the nature of the environment, bold wide- } \\
\text { ranging acts are necessary to achieve the firm's objectives }\end{array}$ & .328 & .102 & .413 & .775 \\
\hline High-risk projects with chances of very high returns & .267 & .083 & .336 & .630 \\
\hline $\begin{array}{l}\text { Typically adopts a very competitive, 'undo-the- } \\
\text { competitors' philosophy }\end{array}$ & .214 & .066 & .269 & .505 \\
\hline $\begin{array}{l}\text { Is very often the first to introduce new products/services, } \\
\text { administrative techniques, operating technologies, etc. }\end{array}$ & .268 & .083 & .337 & .633 \\
\hline $\begin{array}{l}\text { Changes in product or service lines have usually been } \\
\text { quite dramatic }\end{array}$ & .281 & .087 & .353 & .663 \\
\hline $\begin{array}{l}\text { A strong emphasis on research and development, } \\
\text { technological leadership and innovation }\end{array}$ & .236 & .073 & .297 & .557 \\
\hline
\end{tabular}

Table III.

Descriptive Statistics and Correlations between Clustering Variables $(* \mathrm{p}<.05, * * \mathrm{p}<.01)$

\begin{tabular}{lllllll}
\hline & DYN & EO & IS & GSM & Size & Age \\
\hline Mean & 4.10 & 4.08 & 4.19 & 3.28 & 30.04 & 35.93 \\
Standard Deviation & 1.36 & .99 & 1.32 & .65 & 19.82 & 31.23 \\
Cronbach's Alpha & .818 & .821 & .800 & .616 & & \\
Environmental Dynamism (DYN) & 1 & & & & & \\
Entrepreneurial Orientation (EO) & $.351^{* *}$ & 1 & & & & \\
Informal Structure (IS) & .087 & .080 & 1 & & & \\
Generative Strategy-Making (GSM) & $.170^{* *}$ & $.435^{* *}$ & $.199^{* *}$ & 1 & & \\
Size (FTEs) & -.017 & .094 & -.084 & -.003 & 1 & \\
Age (months) & .007 & $-.135^{*}$ & .010 & -.045 & .093 & 1 \\
\hline
\end{tabular}


Table IV.

Comparison of Mean Values for the Clusters

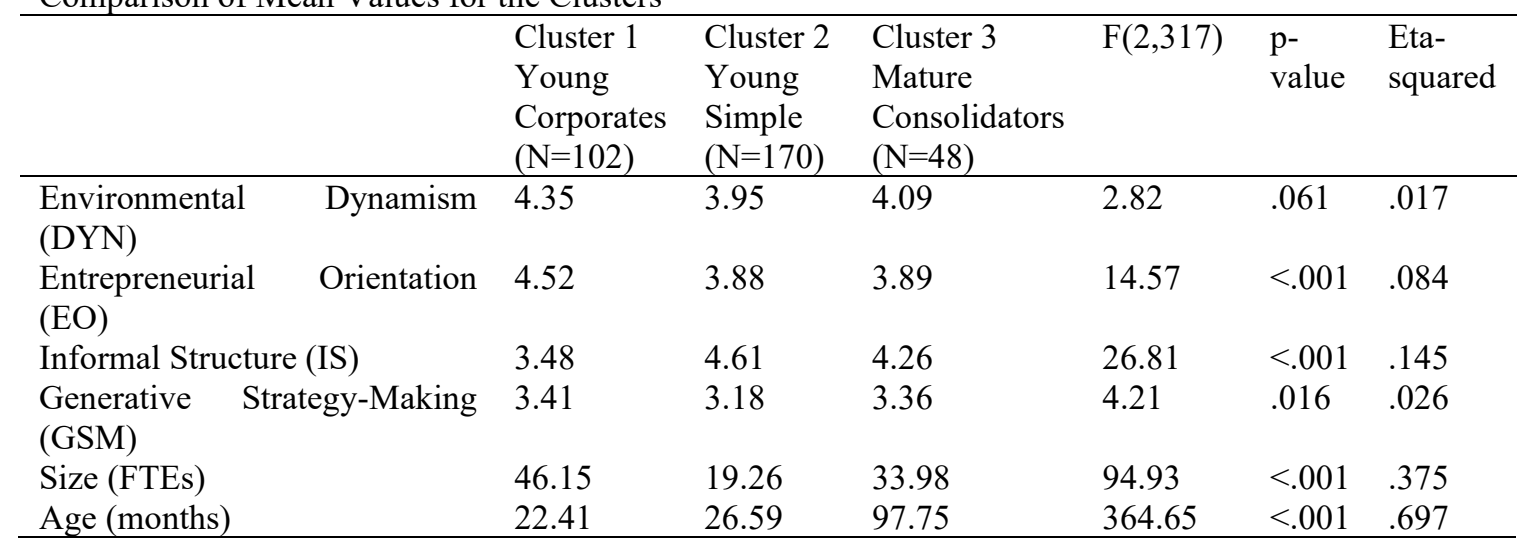

Table V.

Industry Differences for Clusters

\begin{tabular}{lllllll}
\hline Clusters & & \multicolumn{2}{l}{$\begin{array}{l}\text { Industry Category } \\
\text { Services }\end{array}$} & Manufacturing & Construction & $\begin{array}{l}\text { Retail/ } \\
\text { wholesale }\end{array}$ \\
\hline Cluster 1: & Count & 34 & 44 & 14 & 10 & 102 \\
Young Corporates & $\%$ & $42.0 \%$ & $31.4 \%$ & $29.2 \%$ & $19.6 \%$ & $31.9 \%$ \\
Cluster 2: & Count & 34 & 75 & 31 & 30 & 170 \\
Young Simple & $\%$ & $42.0 \%$ & $53.6 \%$ & $64.6 \%$ & $58.8 \%$ & $53.1 \%$ \\
Cluster 3: & Count & 13 & 21 & 3 & 11 & 48 \\
Mature Consolidators & $\%$ & $16.0 \%$ & $15.0 \%$ & $6.3 \%$ & $21.6 \%$ & $15.0 \%$ \\
Total & Count & 81 & 140 & 48 & 51 & 320 \\
& $\%$ & $100.0 \%$ & $100.0 \%$ & $100.0 \%$ & $100.0 \%$ & $100.0 \%$ \\
\hline
\end{tabular}

Table VI.

Performance Comparisons for Clusters while Controlling for Industry Sector

\begin{tabular}{llll}
\hline Cluster Number & 1 & 2 & 3 \\
\hline Configuration & Young Corporates & Young Simple & Mature Consolidators \\
Number of Firms & 102 & 170 & 48 \\
Performance Marginal Means & 148.13 & 136.04 & 140.66 \\
\hline
\end{tabular}

Table VII.

Performance Comparisons for Industry Sector while Controlling for Cluster

\begin{tabular}{lllll}
\hline Industry Category & Services & Manufacturing & Construction & Retail/Wholesale \\
\hline Number of Firms & 81 & 140 & 48 & 51 \\
Performance Marginal Means & 134.25 & 136.95 & 140.25 & 154.99 \\
\hline
\end{tabular}

Table VIII.

Descriptions of Clusters

\begin{tabular}{llll}
\hline & $\begin{array}{l}\text { Cluster 1 } \\
\text { Young Corporates } \\
(\mathrm{N}=102)\end{array}$ & $\begin{array}{l}\text { Cluster 2 } \\
\text { Young Simple } \\
(\mathrm{N}=170)\end{array}$ & $\begin{array}{l}\text { Cluster 3 } \\
\text { Mature Consolidators } \\
(\mathrm{N}=48)\end{array}$ \\
\hline Environmental Dynamism & Highly Dynamic & Less Dynamic & Moderate dynamism \\
Informal Structure & Formal & Informal & Some informality \\
Entrepreneurial Orientation & High & Moderate & Moderate \\
Generative Strategy-Making & High & Lower & Moderate \\
Size (FTEs) & Largest & Small & Medium \\
Age (months) & Early stage & Early stage & Mature \\
\hline
\end{tabular}

